book. This 'do it yourself' approach was to remain a characteristic feature of Gray's work throughout his life.

From school, he won an Exhibition at Trinity College, Cambridge, and two years later took Part I of the Tripos in physics, chomistry, mathematics and mineralogy, and was awarded first-class honours. Proceeding to Part II in physics, ho again achieved a first and was able to commence research at the Cavendish Laboratory during the exciting period of Rutherford's professorship. In 1930 he took his Ph.D. and received a Fellowship at Trinity.

His work at this period was concerned with the scattering and absorption of $\gamma$-rays, and in his first publication (1929) ho enunciated the cavity ionization principle, which had previously been described by Bragg in 1912, although Bragg's work was unknown to Gray at the time. This theory, which is fundamental to $\gamma$-ray dosimotry, became known as the Bragg-Gray principle.

Despite his success in pure physics, he began to find the subject not completely satisfying, and he felt the need to do something of more obvious value for his fellow men. An offer to come to Mount Vernon Hospital as physicist appealed very strongly to him and he took up the position in 1933. Although his work at Mount Vernon was primarily concerned with the accurate measurement of ionizing radiation, he began to take an interest in biological problems under the guidance of that remarkable man, Dr. J. C. Mottram. Before leaving Cambridge, he had begun a fruitful collaboration with F. G. Spear, of the Strangeways Laboratory, studying the effect of neutrons on hen eggs. The noutron source available to them proving to be too weak, Gray, with the collaboration of John Read, built a highly effective neutron generator for

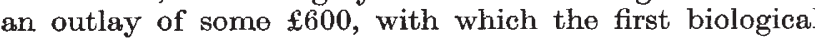
results were obtained in 1938 . At this time, Read and Gray suggested a unit, the Energy Unit, which was applicable to all forms of ionizing radiation and was almost identical with the rad unit adopted by the International Commission on Radiological Units and Measurements some fifteen years later. During the Second World War, when he was working alone, he began to consider the dynamies of cellular population changes underlying the gross changes in behaviour of a bean root following irradiation, thus anticipating one of the focal points of interest in modern radiobiology.

In 1946 Gray went to the Medical Research Council Radiotherapeutic Research Unit, as senior physicist, and in 1950 was promoted to deputy director. Here, he had overall responsibility for building up several teams to carry out ambitious projects in radiation research, the construction of a cyclotron, the development of radioisotopes in research, and general radiobiology. This heavy administrative load left little time for his personal researches, but his wise choice of staff is reflected in the advances in radiobiology made by his group. The classic investigations of Howard and Pelc on the relation of DNA synthesis to the mitotic cycle, and of Miss Alper on bacteriophage, date from this period.

In 1952 Dr. Gray initiated a programme of research on the oxygen effect in radiobiology, and its relation to radiotherapy. Those who had the good fortune to work under Hal Gray at that time will always remember his boyish and generous enthusiasm, which infected all those noar to him. Within six months the main outlines of the picture had been established-a picture which still inspires much of present research in radiobiology. It was characteristic of Hal's disarming modesty that his collaborators had the greatest difficulty in persuading him to be the first author of the paper which recorded this work.

In 1953 Gray resigned his position at Hammersmith, following disagreements on scientific policy. Thanks very largely to the good offices of the late Lord Horder, who placed great faith in Gray, the British Empire Cancer Campaign undertook to finance a now Unit at Mount
Vernon, where he would be director with freedom to pursue his own lines of research.

With considerable foresight, Gray planned the use of a linear accelerator for the development of pulse radiolysis methods, in collaboration with J. W. Boag, a technique which has already revolutionized radiation chemistry. At the same time, he gathered around him a small group whose basic training lay in physics, chemistry, biochemistry, biology and medicino, since he believed strongly that collaborative studies by such a group offered the best hope for advance in an inter-disciplinary field. It was also a great delight to him to return to experimental work, which he did with undiminished energy, planning experiments which made few concessions to human requirements for sleep and food.

He had no love of committees, but he bravely accepted the administrative burdens which were placed on him. His work for the International Commission on Radiological Units will be particularly remembered, and the personal effort which he put in as president of the second International Congress of Radiation Research had a lot to do with the acknowledged success of that meeting.

Gray recoived many honours in recognition of his work, but two he prized highly were American awards, the Judd Award in 1954 and the Bertner Foundation Award in 1964. He was elected Fellow of the Royal Society in 1961 and received an Honorary D.Sc. at Leeds in 1962.

No catalogue of publications or prizes gives a true picture of Hal Gray's contribution to radiobiology. $\mathrm{He}$ delighted in helping other workers, particularly the younger ones, and he never grudged the time devoted to giving help and advice. Even an anonymous referee's comment would engage the whole of his great powers of critical appraisal and constructive comment. Varied and remarkable as his contributions were, it is certain that he will be remembered by those who knew him, not only as a great scientist, but also as a great man.

O. C. A. ScotT

\section{Dr. O. S. Sinnatt}

Dr. Oliver Sturdy SinnatT, professor of aeronautical science in the Royal Air Force College, Cranwell, from 1920 until 1940, died on May 28, 1965, at the age of eighty-two. Dr. Sinnatt was born in Liverpool on September 6, 1882, and educated at the College of Technology, Manchester, and the Owens College (later University of Manchester). He graduated B.Sc. in 1904, M.Sc. in 1907, D.Sc. (London) in 1919, and was elected Associate Fellow of the Royal Aeronautical Society in October 1924. After a year as master of engineering at the Carpenters' Technical Institute, Stratford, he joined the staff of King's College, London, in 1905 as a demonstrator, becoming a senior demonstrator and then a lecturer in the Department of Mechanical Engineering.

During the early part of the First World War he held various posts with the University of London Officers' Training Corps; for a period he was in charge of the Training Camp, Perivale. He was afterwards transferred to the London Regiment and posted to France early in 1917 , rising to be second in command of the $2 / 2$ Battalion of that Regiment.

He was severely wounded at Poelcappelle in 1917 and awarded the Military Cross in 1918. He joined the Air Ministry as a technical officer (Instrument Section) in 1918. He was appointed professor of aeronautical science at the Cadet College, Cranwell, in 1920.

In 1940, Dr. Sinnatt was appointed to the School of Aeronautical Engineering, Henlow, as senior education officer, where he remained until his retirement in 1942.

In 1920 he married Marjorie Helen, the only daughter of the late W. R. Randall, by whom he had two sons, the elder of whom was killed in action in 1944 .

C. E. P. Sutthe 